compilation of a great index for the use of taxonomists, the "Index Kewensis"; the aim of the German physiologists was to find a better basis of taxonomy (one of the negative results of which is that to-day real systematic botany is but scantily touched upon in British universities); and the efforts of the ecologists, geneticists and cytologists can have but one real object-the ultimate reclassification of living organisms.

Among the tendencies of the present time, it is possible to detect an impatience with the existing forms of taxonomy; but any attempt to alter such forms without very profound consideration and fair trial would seem likely to lead to a chaos similar to that from which Linnæus reseued the learned world. Often without being able to read with any ease the Latin works of the older naturalists, some of the modern workers appear to be inclined to cut adrift entirely from the past. The remedy surely lies in a more careful consideration of the philosophical ideas upon which all taxonomy must be based.

\title{
A Discontinued Darwin Medal
}

\section{By T. E. James}

$\mathrm{T}$ HE rise and mutual development in Great Britain of provincial natural history and literary societies, microscopical clubs and field clubs is one of the stories of nineteenth century science that scarcely requires iteration. Yet in regard to one of these, the Midland Union of Natural History Societies, an amalgamation of 1878, due in the main to the efforts of Mr. Lawson Tait, F.R.C.S., of Birmingham, there is a connexion of Darwinian interest in the Union's institution of a Darwin Medal, which in course of time has lapsed in award, and possibly is now altogether out of mind.

The medal bore on the obverse the portrait-bust of Charles Darwin in bas-relief and the reverse a branch of coral ; while the medal itself was the work of Joseph Moore(1817-1901), a well-known medallistsculptor and die-sinker in Birmingham.* Why the award of this medal ceased will be considered presently. Apart from the Royal Society's Darwin Medal (the first award of which was not made until 1890 ), there would appear now to be no medallic gift in Great Britain which periodically com. memorates the researches of the great naturalist in this way.

The idea of an amalgamation of the numerous scientific and literary societies already existing in various parts of the Midland counties took practical shape in 1878 as above mentioned, and a journal called the Midland Naturalist was started as the organ of the Union; the journal appeared successfully down to the end of the year 1893. It was an effective and highly popular medium of intercommunication, but like other official fusions of the period, strength of membership carried latent weaknesses. The magazine eventually became an onerous task, its issue resting on the efforts of the zealous minority.

Returning to the Darwin Medal of the Midland

- Joseph Moore also designed a medal for the British Association meeting at Birmingham in 1849 and at Cheltenham in 1856.
Union, it appears that at the annual meeting held in 1880 at Nottingham, a suggestion was made by Mr. W. Jerome Harrison for the foundation of a yearly prize which should have as an objective the encouragement of original research connected with the natural history of the Midlands. Regarded favourably, it was unanimously agreed to institute an annual Darwin Prize of the value of $£ 10$, to include a gold medal denominated the Darwin Medal, for a paper embodying original research contributed by a member of the Union for publication in the Midland Naturalist. Incidentally, it may be said that Charles Darwin was a subscriber from the first to this publication.

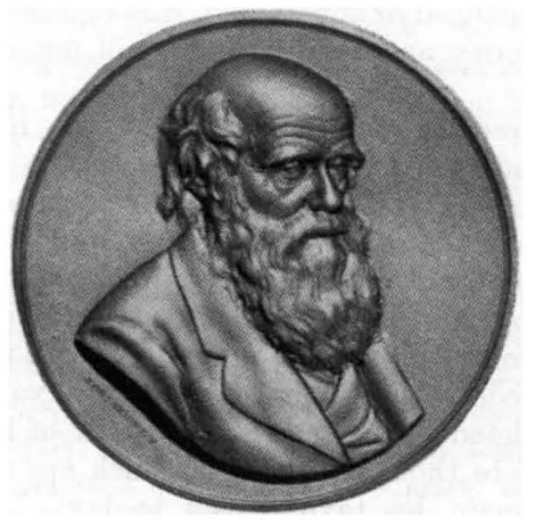

Darwin Medal of the Midland Union of Natural History Societies.

Steps were taken to acquaint Darwin with the proposal and to ask his permission to adopt his name. Darwin replied as follows:

"I request that you will be so good as to inform the members of the Committee that their wish to name the medal after me is a very great honour, which I gladly accept. It is particularly pleasing to me to have my name connected, in however indirect a manner, with a scheme for advancing science-the study of which has been my chief source of happiness throughout life." 
This cordial letter is not recorded in the "Life and Letters" ; but somewhere perhaps the original may be in existence.

Regarding the provision of regulations for the "Darwin Prize", it was decided that the subjects for each of the three years ensuing should be geology, zoology and archæology. The following committee of five adjudicators was chosen: Dr. Thomas Wright, the Rev. George Deane, Prof. Charles Lapworth, J. J. Harris Teall (afterwards Sir Jethro Teall) and W. Jerome Harrison. The first recipient of the gold medal, for the year 1881, was Edward Wilson, of Nottingham, for his paper "The Permian Formation in the North-east of England". The award for the year 1882, in zoology, went to Prof. A. Milnes Marshall, M.D., and W. P. Marshall, M.Inst.C.E., for their joint paper on the "Pennatulida". Space forbids naming the adjudicators. The medal was presented at the annual meeting held at Tamworth in June 1883.

At this meeting it was reported also that a bronze copy of the medal had been sent to the family of the late Charles Darwin, and that Mr. W. Erasmus Darwin, writing from Basset, Southampton, on December 14, 1882, had expressed the opinion that it embodied a striking likeness of his father, who had much appreciated its foundation.

Awards continued, mostly yearly, but always subject to the receipt of meritorious papers. Mention may be made of the annual meeting of 1889, held at Oxford, with Mr. (now Sir Edward) E. B. Poulton, F.R.S., as president of the Union. His address bore the title "Theories of Heredity". We hear of "trenchant criticism" of the word "heredity" by Lawson Tait, and a "lively passage of arms" thereon with Francis Galton. The Darwin Medal for the year was handed to T. W. Walker, for a thesis on a geological subject.

So far back as 1882 a note of warning had been given in the Midland Naturalist that an endowment fund of $£ 250$ would be required if the gift of a gold medal was to continue as a permanent memorial. Alas! this object was never achieved; the Union sailed over uncharted and uncertain waters, and some indeed of its constituent bodies were bad sailors in Darwinian days. The Midland Naturalist ceased publication at the close of 1893 , and the Darwin Medal became a final award in 1895 with its allocation to Dr. Walter E. Collinge, now keeper of the York Museum, for studies in comparative anatomy.

\section{Obituary Notices}

\section{Mr. Hugh Ramage}

$\mathrm{T}$ HE death of Mr. Hugh Ramage, on April 16, at seventy-three years of age, will be deeply regretted by all who knew him. He was one of the most unassuming of men, yet his work in certain fields of spectroscopy was of a very high order, and his devotion to these studies in the leisure hours of a busy life manifested a spirit of selfsacrifice in the pursuit of scientific knowledge not often found at any time.

Mr. Ramage was born on March 31, 1865, at Wolverton, Bucks, but both his father and his mother were natives of Catrine, Ayrshire. He left school at twelve years of age, and a year later, after his parents had removed to Crewe, he entered the L.N.W.R. carriage works there in the telegraph office, his duties being to work the single needle telegraph instrument. While in this position, and afterwards when he became an apprentice in coach-making, he attended evening classes in elementary scientific subjects and mathematics at the Mechanics' Institute. Probably on account of these studies, he was eventu. ally transferred to the laboratory of the locomotive works and became engaged in analytical work. When twenty-one years of age, he entered for the annual competition for National Scholarships or Royal Exhibitions, then awarded on highest successes in the Science and Art Department's examinations. As the result, he obtained a Royal Exhibition tenable at the Royal College of Science, Dublin, which he entered in October 1886.

After completing his course at the Royal College of Science, Mr. Ramage returned to the Crewe laboratory in 1889 under Joseph Reddrop, and while there carried out investigations on the bismuthate method of estimating manganese and the estimation of phosphorus and carbon in mild steels. He left Crewe in 1891 to become demonstrator in chemistry under Prof. (afterwards Sir Walter) Hartley at the Royal College of Science, Dublin; and in the following year he began to assist Sir Walter in researches on flame spectra. One of the chief objects in view was the study of Bessemer flame spectra; and the results obtained were valuable contributions to the knowledge of the thermo-chemistry of the Bessemer process. It was in conjunction with Mr. Ramage that Sir Walter Hartley discovered the existence of the bands in the flame spectra of many metals and from a study of these was able to draw important conclusions about the relation between the band and line spectra of the same element.

Mr. Ramage's introduction to the use of the spectroscope in chemistry in association with Sir Walter Hartley determined his main scientific interests and activities throughout the rest of his life. In 1899 he left Dublin and went to Cambridge 